\title{
Benign Great Vessel Neoplasm
}

National Cancer Institute

\section{Source}

National Cancer Institute. Benign Great Vessel Neoplasm. NCI Thesaurus. Code C8539.

A benign neoplasm involving the great vessel. 